Keywords: Saltstone

Hydraulic Conductivity

Permeameter

Retention: Permanent

\title{
Hydraulic Conductivity of Saltstone Formulated Using 1Q11, 2Q11 and 3Q11 Tank 50 Slurry Samples
}

M.M. Reigel
R.L. Nichols

June 2012

Savannah River National Laboratory Savannah River Nuclear Solutions Aiken, SC 29808

Prepared for the U.S. Department of Energy under contract number DE-AC09-08SR22470. 
SRNL-STI-2012-00259

Revision 0

\section{DISCLAIMER}

This work was prepared under an agreement with and funded by the U.S. Government. Neither the U.S. Government or its employees, nor any of its contractors, subcontractors or their employees, makes any express or implied:

1. warranty or assumes any legal liability for the accuracy, completeness, or for the use or results of such use of any information, product, or process disclosed; or

2. representation that such use or results of such use would not infringe privately owned rights; or

3. endorsement or recommendation of any specifically identified commercial product, process, or service.

Any views and opinions of authors expressed in this work do not necessarily state or reflect those of the United States Government, or its contractors, or subcontractors.

\section{Printed in the United States of America \\ Prepared for \\ U.S. Department of Energy}




\section{REVIEWS AND APPROVALS}

AUTHORS:

M.M. Reigel, Engineering Process Development

Date

R.L. Nichols, Geosciences

Date

TECHNICAL REVIEW:

K.L. Dixon, Geosciences

Date

APPROVAL:

K.M. Fox, Manager

Date

Engineering Process Development

T.O. Oliver, Manager

Date

Geosciences

S.L. Marra, Manager

Date

Environmental \& Chemical Process Technology Research Programs

J.E. Occhipinti, Manager

Date

Waste Solidification Engineering 


\section{EXECUTIVE SUMMARY}

As part of the Saltstone formulation work requested by Waste Solidification Engineering (WSE), Savannah River National Laboratory (SRNL) was tasked with preparing Saltstone samples for fresh property analysis and hydraulic conductivity measurements using actual Tank 50 salt solution rather than simulated salt solution. Samples of low level waste salt solution collected from Tank $50 \mathrm{H}$ during the first, second, and third quarters of 2011 were used to formulate the Saltstone samples. The salt solution was mixed with premix (45 wt \% slag, $45 \mathrm{wt} \%$ fly ash, and $10 \mathrm{wt} \%$ cement), in a ratio consistent with facility operating conditions during the quarter of interest. The fresh properties (gel, set, bleed) of each mix were evaluated and compared to the recommended acceptance criteria for the Saltstone Production Facility. ASTM D5084-03, Method $\mathrm{C}$ was used to measure the hydraulic conductivity of the Saltstone samples. The hydraulic conductivity of Saltstone samples prepared from 1Q11 and 2Q11 samples of Tank $50 \mathrm{H}$ is $4.2 \mathrm{E}-9 \mathrm{~cm} / \mathrm{sec}$ and $2.6 \mathrm{E}-9 \mathrm{~cm} / \mathrm{sec}$, respectively. Two additional $2 \mathrm{Q} 11$ and one 3Q11 sample were not successfully tested due to the inability to achieve stable readings during saturation and testing. The hydraulic conductivity of the samples made from Tank $50 \mathrm{H}$ salt solution compare well to samples prepared with simulated salt solution and cured under similar conditions (1.4E-9 $-4.9 \mathrm{E}-8 \mathrm{~cm} / \mathrm{sec})$. 


\section{TABLE OF CONTENTS}

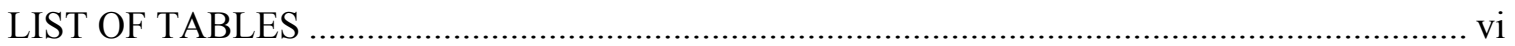

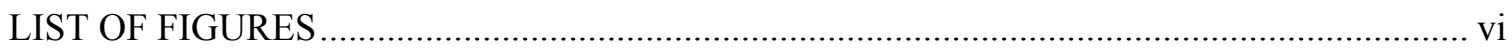

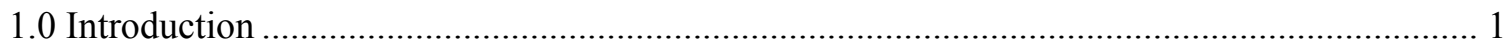

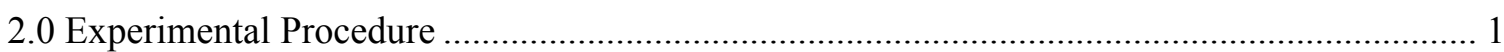

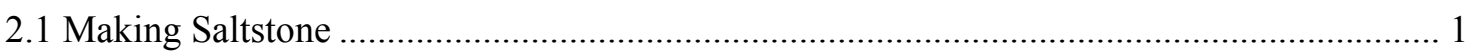

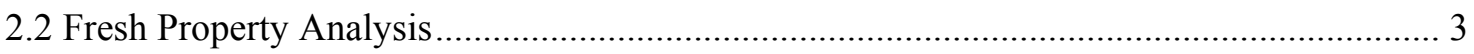

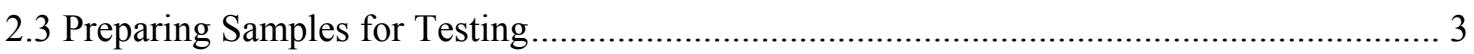

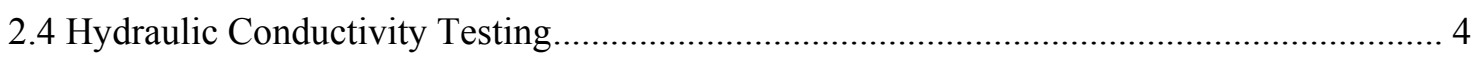

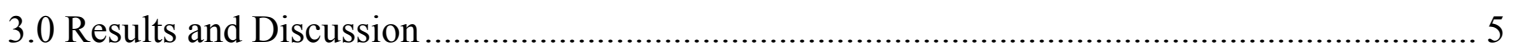

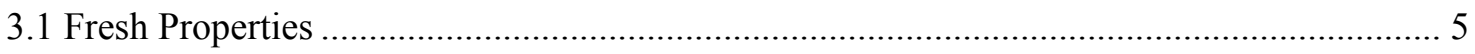

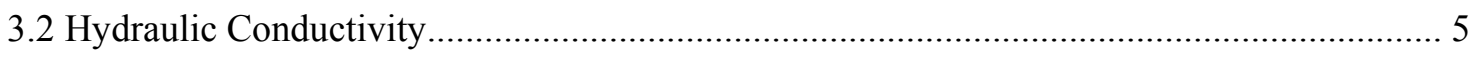

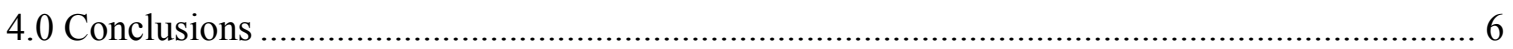

5.0 Recommendations, Path Forward or Future Work …............................................................... 6

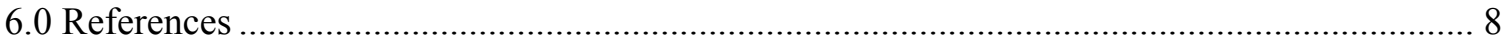




\section{LIST OF TABLES}

Table 1. Physical properties of 2011 Tank 50H salt solutions

Table 2. Formulations for Saltstone prepared with 2011 Tank 50H salt solutions based on SPF

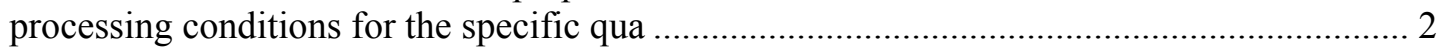

Table 3. Dose readings taken during sample preparation............................................................ 3

Table 4. Simulated Tank $50 \mathrm{H}$ salt solution used as the saturating liquid and permeant for hydraulic conductivity testing ....................................................................................... 4

Table 5. Recommended fresh property criteria for an acceptable formulation .............................. 5

Table 6. Results of fresh property testing on 1Q11, 2Q11, and 3Q11 Saltstone samples .............. 5

Table 7. Results of flexible wall permeameter testing of 1Q11 and 2Q11-A Saltstone samples .... 5

\section{LIST OF FIGURES}

Figure 1. Flowchart of Saltstone preparation and testing ........................................................ 1

Figure 2. Preparation of molded saltstone samples for hydraulic conductivity testing, (a) removal from 2 inch diameter plastic mold, (b) cutting to length..................................................... 4

Figure 3. Irregular surface of the 3Q11-B sample due to entrained air ....................................... 6 


\section{LIST OF ABBREVIATIONS}

$\begin{array}{ll}\text { SDF } & \text { Saltstone Disposal Facility } \\ \text { SPF } & \text { Saltstone Processing Facility } \\ \text { SRNL } & \text { Savannah River National Laboratory } \\ \text { SS } & \text { Stainless steel } \\ \text { TCLP } & \text { Toxicity Characteristic Leaching Procedure } \\ \text { TTQAP } & \text { Task Technical and Quality Assurance Plan } \\ \text { TTR } & \text { Technical Task Request } \\ \text { WAC } & \text { Waste Acceptance Criteria } \\ \text { WSE } & \text { Waste Solidification Engineering } \\ \text { wt } \% & \text { Weight Percent }\end{array}$




\subsection{Introduction}

Savannah River National Laboratory (SRNL) receives samples of Tank $50 \mathrm{H}$ every quarter to support regulatory compliance analyses. After material is utilized for Waste Acceptance Criteria (WAC) and Toxicity Characteristic Leaching Procedure (TCLP) analyses, the remaining sample from each quarter is available for formulation testing. As part of the Saltstone formulation work requested by Waste Solidification Engineering (WSE), SRNL was tasked with performing hydraulic conductivity measurements on Saltstone samples made in the laboratory with actual Tank $50 \mathrm{H}$ salt solution ${ }^{1}$ as described in the task technical and quality assurance plan (TTQAP). ${ }^{2}$ The results were compared to samples made from simulated salt solution cured under similar conditions $^{3}$

Material collected from Tank 50H during the first, second, and third quarters of 2011 was used to make Saltstone samples for evaluating fresh properties and for hydraulic conductivity testing. Samples were formulated based on the operating conditions of the Saltstone Processing Facility (SPF) during the quarter of interest. When enough material remained after making the first set of samples, the formulation was varied, by adding or removing admixes, to determine the effect of changing the starting mix on the fresh properties and hydraulic conductivity of laboratory prepared Saltstone samples.

\subsection{Experimental Procedure}

Saltstone samples were prepared by mixing the premix materials and Tank $50 \mathrm{H}$ slurry followed by curing for at least 28 days at room temperature. After mixing, the fresh properties of the slurry (gel, set, and bleed) were tested. Once cured, the samples were cut to size, saturated, and tested for hydraulic conductivity. Figure 1 shows the flowchart for sample formulation and testing.

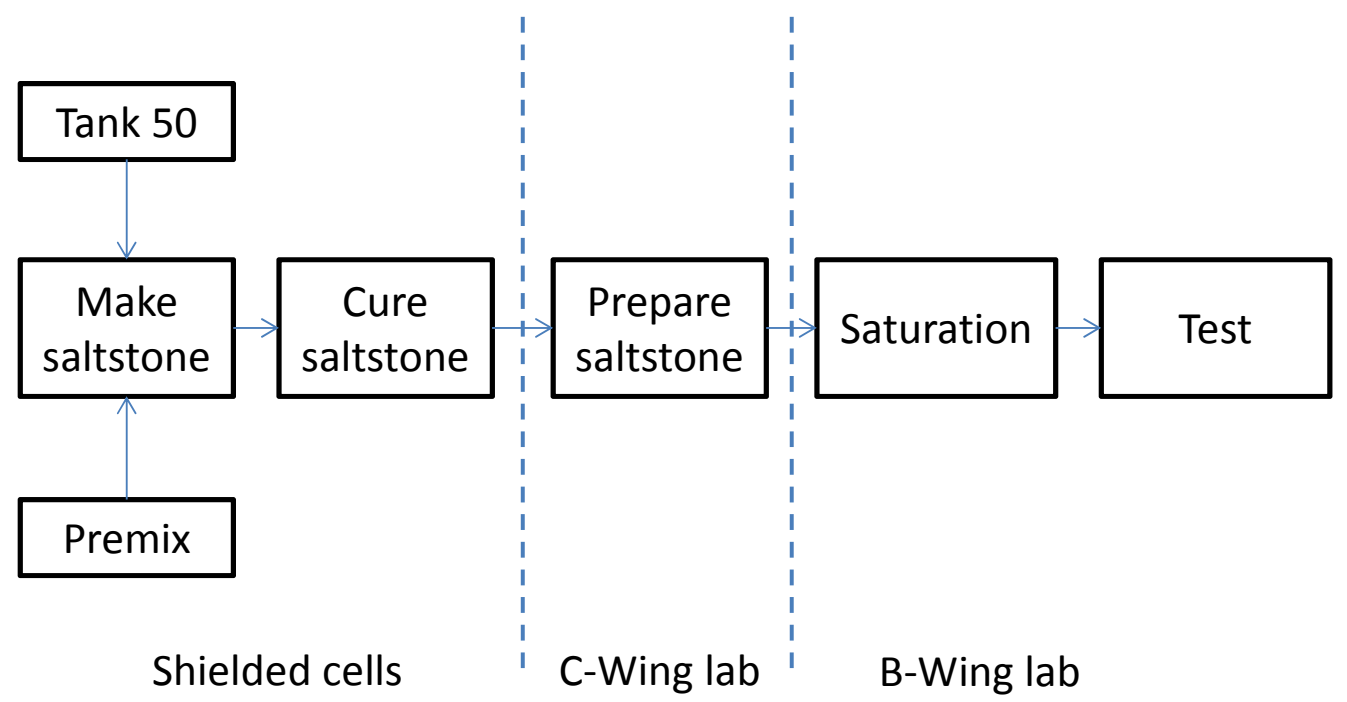

Figure 1. Flowchart of Saltstone preparation and testing

\subsection{Making Saltstone}

Saltstone samples were prepared from samples of Tank $50 \mathrm{H}$ salt solution collected during the first $(1 \mathrm{Q} 11)^{4}$ second $(2 \mathrm{Q} 11)^{5}$ and third $(3 \mathrm{Q} 11)^{6}$ quarters of 2011. Premix (cement, slag, and fly ash), obtained from the SPF, was mixed with the Tank $50 \mathrm{H}$ salt solution in a specific water to premix ratio according to the facility operating conditions for the quarter of interest as provided by SPF engineering personnel (Table 1). ${ }^{7}$ 
SRNL-STI-2012-00259

Revision 0

Table 1. SPF processing conditions for the first, second, and third quarters of 2011

\begin{tabular}{||c|c|c|c|c|}
\hline Processing Parameter & Units & 1Q11 & 2Q11 & 3Q11 \\
\hline Dry Feed Rate & Tons $/ \mathrm{hr}$ & 33 & 33 & 33 \\
\hline Specific gravity set point & $\mathrm{g} / \mathrm{mL}$ & 1.19 & not provided & 1.2 \\
\hline Water to Premix ratio & Unitless & 0.60 & 0.60 & 0.59 \\
\hline Daratard-17 rate & $\mathrm{gpm}$ & 0 & 0 & $0.23+/-1$ \\
\hline Q2-1383A rate & $\mathrm{gpm}$ & $0.1-0.25$ & $0.1-0.25$ & $0.1-0.25$ \\
\hline
\end{tabular}

When enough Tank $50 \mathrm{H}$ salt solution remained after making the first set of samples, the formulation was varied, by adding or removing admixes, to determine the effect on the fresh properties and hydraulic conductivity of laboratory prepared Saltstone samples. Table 2 shows the specific sample formulations for the laboratory prepared Saltstone samples.

Table 2. Formulations for Saltstone prepared with 2011 Tank $50 \mathrm{H}$ salt solutions based on SPF processing conditions for the specific quarter

\begin{tabular}{||c|c|c|c|c|c||}
\hline Parameter & Units & 1Q11 & 2Q11 A \& B & 2Q11 C & 3Q11 A \& B \\
\hline \hline Density & g/mL & 1.1995 & \multicolumn{2}{|c|}{1.2048} & 1.2152 \\
\hline Total Solids & wt \% & 24.43 & \multicolumn{2}{|c|}{24.80} & 25.20 \\
\hline Water Content & wt \% & 75.57 & \multicolumn{2}{|c|}{75.20} & 74.80 \\
\hline Water to Premix ratio & Unitless & 0.60 & 0.60 & 0.60 & 0.59 \\
\hline Q2-1383A & wt \% of premix & 0.03 & 0.03 & 0.03 & 0.03 \\
\hline Daratard 17 & wt \% of premix & 0 & 0 & 0.21 & 0.21 \\
\hline Cement & wt \% in premix & 10 & 10 & 10 & 10 \\
\hline Slag & wt \% in premix & 45 & 45 & 45 & 45 \\
\hline Fly Ash & wt \% in premix & 45 & 45 & 45 & 45 \\
\hline
\end{tabular}

The 1Q11 and 2Q11 Saltstone samples were prepared in the shielded cells using the same preparation method as TCLP samples. ${ }^{8}$ The salt solution, admixtures (Q2-1383A and Daratard 17) and premix materials were combined in a blender and mixed at low speed for one minute, inspected for incorporation of the premix, and then mixed at high speed for an additional two minutes. The grout poured smoothly and without clumps into $2 \times 4$ inch cylinders. After the fresh properties were measured, the cylinders were capped and allowed to sit undisturbed in the shielded cells for at least 28 days at room temperature. After curing, the samples were removed from the shielded cells to a radioactive laboratory hood for subsequent processing for hydraulic conductivity testing.

Since the dose was lower than the 1Q11 and 2Q11 salt solution, the 3Q11 Tank 50H samples were made in a radioactive laboratory hood, following the same procedure for mixing simulated Saltstone samples. ${ }^{3}$ The admixtures, if used, were added to the salt solution. The paddle blade mixer was turned on and the premix materials were added to the liquid. Once all the dry feeds were incorporated, the grout slurry was mixed for approximately three minutes. The mixing was paused for approximately five seconds after the first 30 seconds of mixing to allow entrained air to escape from the grout. The grout poured smoothly and without clumps into $2 \times 4$ inch cylinders. After the fresh properties were measured, the cylinders were capped and allowed to sit 
undisturbed in the hood for at least 28 days at room temperature. After curing, the samples were prepared for testing.

\subsection{Fresh Property Analysis}

The fresh properties measured on the Saltstone mixes are gel time, set, and volume of bleed produced. The gel time is measured by pouring the fluid grout from one cup to the other every 5 minutes until the Saltstone did not flow under its own weight. The standing water is checked one day after mixing and three days after mixing. If liquid is present on top of the sample, it is poured off, weighed, and returned to the top of the sample. The volume percent of standing water is calculated based on the dimensions of the sample and the volume of standing liquid. Set is measured using the Vicat needle apparatus approximately every 12 hours after the sample was poured. The set time is recorded in days.

\subsection{Preparing Samples for Testing}

Extremity, whole body, and skin doses were measured during sample preparation for hydraulic conductivity. The results of these measurements are in Table 3. Samples were removed from the plastic mold, cut to length using a fine toothed saw (Figure 2), and placed in a desiccator for vacuum saturation using a simulated Tank $50 \mathrm{H}$ salt solution prior to hydraulic conductivity testing. The simulant was used both as the saturating liquid and permeant for hydraulic conductivity testing (Table 4).

Table 3. Dose readings taken during sample preparation

\begin{tabular}{||c|c|c|c|c||}
\hline Sample & $\begin{array}{c}\text { Extremity } \\
\text { (mrem) }\end{array}$ & $\begin{array}{c}\text { Whole Body } \\
\text { (mrem) }\end{array}$ & $\begin{array}{c}\text { Skin } \\
\text { (mrem) }\end{array}$ & Comment \\
\hline \hline 1Q11 & NM & NM & NM & -- \\
\hline 2Q11-A & 61 & 3 & 27 & $60000 \mathrm{dpm} \beta \gamma, 1000 \mathrm{dpm} \alpha$ \\
\hline 2Q11-B & 204 & 4 & 28 & -- \\
\hline 2Q11-C & 35 & 3 & 15 & ND dpm $\beta \gamma, 500 \mathrm{dpm} \alpha$ \\
\hline 3Q11-A & 70 & 4 & 17 & \multirow{2}{*}{$<1000 \mathrm{dpm} \beta \gamma,<200 \mathrm{dpm} \alpha$} \\
\hline
\end{tabular}

$\mathrm{NM}$ - not measured 


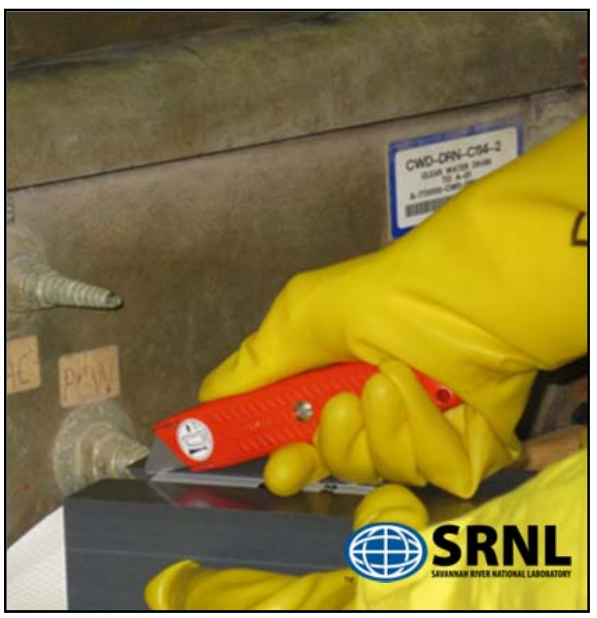

(a)

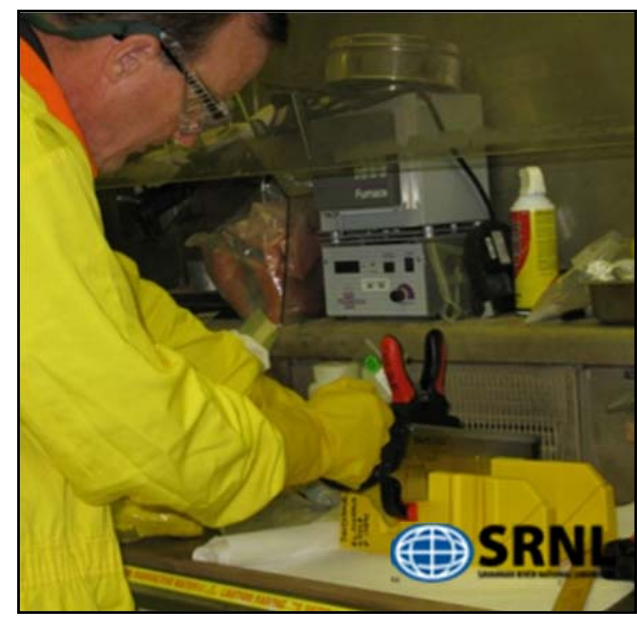

(b)

Figure 2. Preparation of molded saltstone samples for hydraulic conductivity testing, (a) removal from 2 inch diameter plastic mold, (b) cutting to length

Table 4. Simulated Tank $50 \mathrm{H}$ salt solution used as the saturating liquid and permeant for hydraulic conductivity testing

\begin{tabular}{|c|c|c|}
\hline Compound & Molarity & g/mol \\
\hline \hline $50 \%$ by Weight $\mathrm{NaOH}$ & 1.551 & 40.00 \\
\hline $\mathrm{NaNO}_{3}$ & 2.116 & 85.00 \\
\hline $\mathrm{NaNO}_{2}$ & 0.336 & 69.00 \\
\hline $\mathrm{Na}_{2} \mathrm{CO}_{3}$ & 0.148 & 105.99 \\
\hline $\mathrm{Na}_{2} \mathrm{SO}_{4}$ & 0.059 & 142.04 \\
\hline Aluminum Nitrate $\left(9 \mathrm{H}_{2} \mathrm{O}\right)$ & 0.110 & 375.13 \\
\hline Weight Percent Solids & $25.85 \mathrm{wt} \%$ \\
\hline Total Sodium Molarity & \multicolumn{2}{|c|}{$4.42 \mathrm{M}$} \\
\hline \multicolumn{2}{|c|}{$1.2078 \mathrm{~g} / \mathrm{mL}$} \\
\hline \multicolumn{2}{|l}{} \\
\hline
\end{tabular}

\subsection{Hydraulic Conductivity Testing}

Following vacuum saturation, the samples were tested in a flexible wall permeameter using ASTM D5084-03 Method C for determining hydraulic conductivity of saturated materials. ${ }^{9,10}$ The samples were loaded into a tri-axial cell with a glass fiber filter, porous stainless steel (SS) disk, and a SS cap on both ends with a surrounding rubber membrane held in place with O-rings. ${ }^{10}$ Back-pressure saturation was used to complete the saturation of the samples and remove any residual gas bubbles in the sample. ${ }^{10}$ The permeation was started by increasing the influent pressure while keeping the effluent pressure constant to maintain the back-pressure. Testing was considered complete when at least four values of steady hydraulic conductivity were obtained. ${ }^{9,10}$ 


\subsection{Results and Discussion}

\subsection{Fresh Properties}

The fresh properties of the Saltstone mixes help ensure the product can be processed through the facility and transferred to the Saltstone Disposal Facility (SDF) disposal units. The recommended criteria for an acceptable formulation are listed in Table 5.

Table 5. Recommended fresh property criteria for an acceptable formulation

\begin{tabular}{||l|l|l||}
\hline Property & Criterion & Duration \\
\hline \hline Gel Time & Pourable & $20<\mathrm{T}_{\text {gel }}<60$ minutes \\
\hline Standing Water & $1 \%$ by volume $^{\mathrm{a}}$ & 3 days \\
\hline Set Time & $<2.5 \mathrm{~mm}$ penetration by ASTM C 191 & 6 days \\
\hline
\end{tabular}

${ }^{\mathrm{a}}$ 704-Z-4400, Saltstone Grout Lab Analysis

${ }^{\mathrm{b}}$ ASTM C 191-04, Standard Test Method for Time of Setting of Hydraulic Cement by Vicat Needle

The results of the fresh property testing are listed in Table 6. All the samples met the criteria for standing water and set time. However, only the 2Q11 C sample met the criteria for gel time. The results of the 2Q11 formulation study are documented in a memo to WSE. ${ }^{11}$ Although the gel time for the 1Q11 sample is lower than the recommended criteria, further formulation work was not performed since the formulation work was performed after the quarter of interest had passed and there was not enough Tank $50 \mathrm{H}$ material to perform additional testing. The cure time is the total amount of time from when the sample was poured and when it was tested for hydraulic conductivity.

Table 6. Results of fresh property testing on 1Q11, 2Q11, and 3Q11 Saltstone samples

\begin{tabular}{|l|l|c|c|c|c||}
\hline Fresh Property & Units & 1Q11 & 2Q11 A \& B & 2Q11 C & 3Q11 A \& B \\
\hline \hline Gel time & minutes & 10 & $<10$ & 30 & NM \\
\hline 1-day standing water & vol \% & 0 & 0 & 0 & 0 \\
\hline Set & Days & 1 & 1 & 2 & 2 \\
\hline Cure time & Days & 77 & 112 & 112 & 50 \\
\hline
\end{tabular}

\subsection{Hydraulic Conductivity}

The 1Q11 and 2Q11-A Saltstone samples were successfully saturated and tested ( Table 7).

Table 7. Results of flexible wall permeameter testing of 1Q11 and 2Q11-A Saltstone samples

\begin{tabular}{|c|c|c|c|c|}
\hline \multirow{2}{*}{ Sample } & Hydraulic Conductivity & \multicolumn{2}{|c|}{ Test Pressure (psig) } & \multirow{2}{*}{ Gradient } \\
\cline { 3 - 4 } & (cm/sec) & Confining & Pore $^{\mathbf{1}}$ & \\
\hline \hline 1Q11 & $4.2 \mathrm{E}-9$ & 90.7 & 86.5 & 33 \\
\hline 2Q11-A & $2.6 \mathrm{E}-9$ & -- & 49.0 & 29 \\
\hline
\end{tabular}

The results from the 1Q11 and 2Q11-A samples are comparable to hydraulic conductivity measurements on Saltstone samples formulated with salt solution simulants at comparable water to premix ratios. Previous studies show that simulated Saltstone samples cured at room temperature (approximately $20-25{ }^{\circ} \mathrm{C}$ ) have hydraulic conductivities on the order of $1.4 \mathrm{E}-9$ $4.9 \mathrm{E}-8 \mathrm{~cm} / \mathrm{sec}^{3,12}$ Therefore, for laboratory prepared Saltstone samples cured at room temperature, 
the hydraulic conductivity values are on the same order of magnitude using either actual Tank $50 \mathrm{H}$ or simulated salt solution.

The 2Q11-B, 2Q11-C and 3Q11 Saltstone samples were not successfully tested. Several attempts were made to achieve stable back-pressure saturation and test conditions on these Saltstone samples. Stable readings could not be achieved during back-pressure saturation and therefore testing could not be performed. The additional 2Q11 and 3Q11-B samples were too short (due to minimal material available for formulation work) to allow both ends to be cut flush. The irregular end and the presence of small cavities on the surface of the samples from entrained air in the grout may have contributed to the unsuccessful back-pressure saturation and testing. Figure 3 shows the top surface and exterior of the 3Q11-B Saltstone sample. In addition, the salt solution permeant caused valves to malfunction and as a result, testing the 3Q11-A sample was not attempted.

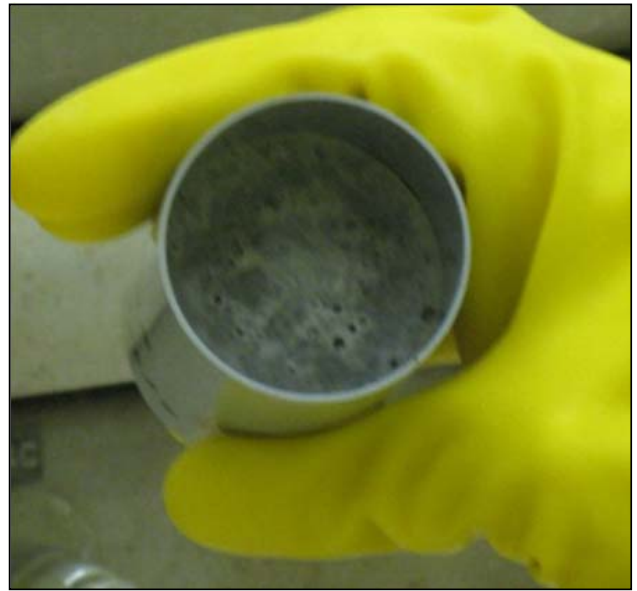

(a)

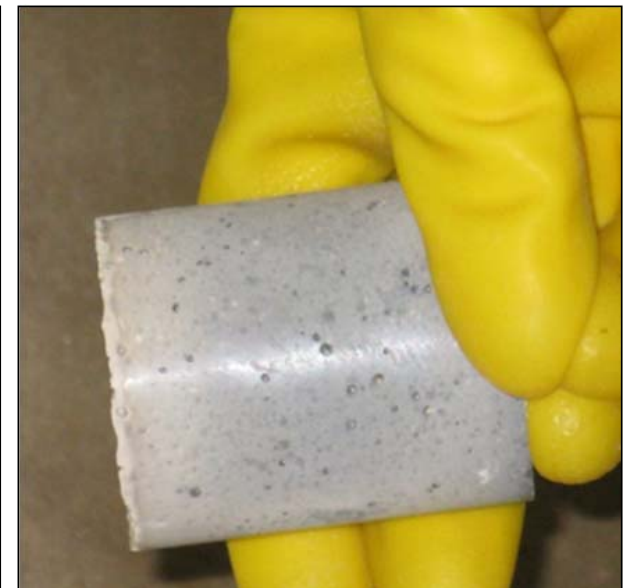

(b)

Figure 3. Irregular surface of the 3Q11-B sample due to entrained air

\subsection{Conclusions}

Two Saltstone samples made from Tank $50 \mathrm{H}$ slurry were successfully analyzed for hydraulic conductivity using ASTM D5084-03, Method C. The hydraulic conductivity of the 1Q11 and 2Q11-A samples of Tank $50 \mathrm{H}$ are $4.2 \mathrm{E}-9 \mathrm{~cm} / \mathrm{sec}$ and $2.6 \mathrm{E}-9 \mathrm{~cm} / \mathrm{sec}$, respectively. These results which are consistent with results from simulated Saltstone samples, indicate that for laboratory prepared Saltstone, the hydraulic conductivity measurements are on the same order of magnitude as actual Tank $50 \mathrm{H}$ or simulated salt solution.

\subsection{Recommendations, Path Forward or Future Work}

Formulation work with the actual Tank $50 \mathrm{H}$ salt solution provides valuable data for processing Saltstone slurry through the SPF. In addition, performing work on the cured properties of Saltstone formulated with actual Tank $50 \mathrm{H}$ salt solution will provide more insight into the performance properties of Saltstone and bridge the gap between simulant and radioactive samples. However, in order to execute this work, additional material will be needed from Tank $50 \mathrm{H}$. Future work for this task would be to work with the Tank Farm to obtain additional material for formulation testing. 
Another path forward will be to research the effect of the permeant used in hydraulic conductivity measurements of Saltstone. If water can be substituted for salt solution for these measurements, the required maintenance on the permeameter can be reduced and the system will be more robust. 


\subsection{References}

1. Staub, A.V., "Technical Task Request - Saltstone Formulation, Quarterly Analyses, TCLP Preparation - FY2011," Savannah River Remediation, HLW-SSF-TTR-2010-0003, Rev. 0, September 14, 2010.

2. Reigel, M.M., "Task Technical and Quality Assurance Plan for SRNL Support of Saltstone Formulation," Savannah River National Laboratory, SRNL-RP-2011-00254, March 2011.

3. Reigel, M.M., Edwards, T.B., and Pickenheim, B.R., "Operational and Compositional Factors that Affect the Performance Properties of ARP/MCU Saltstone Grout," Savannah River National Laboratory, SRNL-STI-2011-00665, February 2012.

4. Reigel, M.M., "Results for the First Quarter 2011 Tank 50 WAC Slurry Sample: Chemical and Radionuclide Contaminant Results," Savannah River National Laboratory, SRNL-STI-2011-00303, May 2011.

5. Eibling, R.E., "Results for the Second Quarter 2011 Tank 50 WAC Slurry Sample: Chemical and Radionuclide Contaminant Results," Savannah River National Laboratory, SRNL-STI-2011-00443, August 2011.

6. Reigel, M.M., "Results for the Third Quarter 2011 Tank 50 WAC Slurry Sample: Chemical and Radionuclide Contaminant Results," Savannah River National Laboratory, SRNL-STI-2011-00574, October 2011.

7. Reigel, M.M., "Saltstone Formulation," Savannah River National Laboratory, SRNL-NB2009-00075, June 17, 2009.

8. Reigel, M.M., "Saltstone 1QCY2011 TCLP Results," Savannah River National Laboratory, SRNL-STI-2011-00262, Rev. 0.

9. $\quad$ "Standard Test Methods for Measurement of Hydraulic Conductivity of Saturated Porous Materials Using a Flexible Wall Permeameter Method C, Falling Head/Rising Tailwater Elevation", D5084-03, ASTM International.

10. Nichols, R.L. and Dixon, K.L., "Permeability Testing of Simulated Saltstone Core and Vault 4 Cell E Saltstone," Savannah River National Laboratory, SRNL-STI-2010-00657, Rev. 0.

11. Reigel, M.M., "Recommended Saltstone Formulation for the Second Quarter 2011," Savannah River National Laboratory, SRNL-L3100-2011-00121, Rev. 0, June 10, 2011.

12. Dixon, K.L., Harbour, J.R., and Phifer, M.A., "Hydraulic and Physical Properties of Saltstone Grout," Savannah River National Laboratory, SRNL-STI-2009-00419, Revision 0, May 2010. 


\section{Distribution}

\begin{tabular}{|l|l|}
\hline S. L. Marra & $773-\mathrm{A}$ \\
\hline S. D. Fink & $773-\mathrm{A}$ \\
\hline K. M. Fox & $999-\mathrm{W}$ \\
\hline B. J. Giddings & $786-5 \mathrm{~A}$ \\
\hline C. C. Herman & $999-\mathrm{W}$ \\
\hline F. M. Pennebaker & $773-42 \mathrm{~A}$ \\
\hline P. M. Almond & $773-43 \mathrm{~A}$ \\
\hline A. D. Cozzi & $999-\mathrm{W}$ \\
\hline R. E. Eibling & $999-\mathrm{W}$ \\
\hline E. K. Hansen & $999-\mathrm{W}$ \\
\hline C. A. Langton & $773-43 \mathrm{~A}$ \\
\hline D. H. Miller & $999-\mathrm{W}$ \\
\hline B. R. Pickenheim & $999-\mathrm{W}$ \\
\hline M. M. Reigel & $999-\mathrm{W}$ \\
\hline M. G. Serrato & $773-42 \mathrm{~A}$ \\
\hline D. B. Stefanko & $773-43 \mathrm{~A}$ \\
\hline P. R. Jackson & $703-46 \mathrm{~A}$ \\
\hline K. H. Subramanian & $249-8 \mathrm{H}$ \\
\hline J. M. Bricker & $704-27 \mathrm{~S}$ \\
\hline K. D. Dixon & $704-14 \mathrm{Z}$ \\
\hline J. N. Leita & $704-\mathrm{Z}$ \\
\hline K. R. Liner & $704-\mathrm{S}$ \\
\hline P. D. Mason & $704-14 Z$ \\
\hline P. W. Norris & $704-29 \mathrm{~S}$ \\
\hline J.E. Occhipinti & $704-\mathrm{S}$ \\
\hline J. W. Ray & $704-\mathrm{S}$ \\
\hline S. C. Shah & $704-14 Z$ \\
\hline D. C. Sherburne & $704-\mathrm{S}$ \\
\hline A. V. Staub & $704-27 \mathrm{~S}$ \\
\hline J. R. Tihey & $704-\mathrm{Z}$ \\
\hline &
\end{tabular}

